\title{
What Ever Happened to Francis Glisson? Albrecht Haller and the Fate of Eighteenth-Century Irritability
}

\section{Guido Giglioni}

The Warburg Institute, London

\section{Argument}

This article investigates the reasons behind the disappearance of Francis Glisson's theory of irritability during the eighteenth century. At a time when natural investigations were becoming increasingly polarized between mind and matter in the attempt to save both man's consciousness and the inert nature of the res extensa, Glisson's notion of a natural perception embedded in matter did not satisfy the new science's basic injunction not to superimpose perceptions and appetites on nature. Knowledge of nature could not be based on knowledge within nature, i.e., on the very knowledge that nature has of itself; or - to look at the same question from the point of view of the human mind - man's consciousness could not be seen as participating in forms of natural selfhood. Albrecht Haller played a key role in this story. Through his experiments, Haller thought he had conclusively demonstrated that the response given by nature when irritated did not betray any natural perceptivity, any inner life, any sentiment interiéur. In doing so, he provided a less bewildering theory of irritability for the rising communities of experimental physiology.

In De natura substantiae energetica (1672) and De ventriculo et intestinis (1677), the anatomist and philosopher Francis Glisson set out to redefine the relationship between the natural operations of the body and various forms of sentient perception along the lines of a new metaphysics of living matter (materia prima as vita primaeva). Such a metaphysical view hinged upon the notion of natural perception. By natural perception Glisson meant an act of original vital reactivity embedded in matter, capable of implementing the most recondite knowledge of life underlying all natural operations. In Glisson's anatomy and philosophy, natural perception played the important role of coordinating the operations of matter, life, and knowledge within a unified view of nature. A key point in Glisson's philosophy was the introduction of a clear distinction between sensibility and the natural activity of matter. While natural perception represented the primordial act of life inherent in every aspect of reality, sense perception was the result of increasingly complex and organized modifications of matter. Glisson characterized the process of irritability as the physiological counterpart of the speculative notion of natural perception and explained its operations in the body as the result of an elementary 
active power in matter, unsentient but teleologically effective nonetheless, capable of imparting design on nature without being aware of it. The decades that followed the publication of Glisson's works witnessed an intriguing development: while the notion of irritability became increasingly popular, the name of Glisson disappeared. ${ }^{1}$

In the evolution of the notion of irritability, Albrecht Haller played a key role. $\mathrm{He}$ had no qualms about acknowledging Glisson's important contribution to the modern definition of vital responsiveness. In the "short history" of irritability appended at the end of his Dissertation on the Sensible and Irritable Parts of Animals (1753), Haller wrote that "Glisson discovered the active force of the elements of our bodies" and "was the first who invented the word Irritability" (Haller [1755] 1936, 4243). ${ }^{2}$ Despite this acknowledgment, however, Haller appropriated the term irritabilitas stripped of all metaphysical connotations. He rejected the idea of irritability as the bodily manifestation of a universal unsentient power embedded in matter; he rigidly demarcated irritability and sensibility, nature and knowledge, body and soul; ultimately, he preferred a compromise, rather theological in tone, to any form of philosophical monism. In this article, I will compare Glisson's and Haller's notions of irritability and will investigate the tensions behind Haller's attempt to elaborate and justify an experimental and operational notion of irritation while avoiding the philosophical implications of the notion of irritability. As will become apparent in this essay, in Glisson's word it was the suffix "-ability" (habilitas, a Latin word denoting an aptitude) that represents the part Haller omitted from his explanatory picture. ${ }^{3}$

Historical accidents and hermeneutical vagaries contributed to the fall into oblivion of Glisson's theory of irritability during the eighteenth century. The similarities with Spinoza's parallelism of thought and matter, already noticed by Henry More in the 1670s, overshadowed Glisson's metaphysics of living matter; Théophile de Bordeu's reading of Jan Baptiste van Helmont as a forerunner of a new theory of sensibility eclipsed Glisson's own interpretation of Helmontian vitalism as a form of unsentient irritability; finally, the extraordinary success on the Continent (especially in France) of the Lockean version of the hypothesis of thinking matter drastically reduced the attention that eighteenth-century savants might have paid to Glisson's notion of perceiving matter. However, apart from these and other historical accidents (including

\footnotetext{
${ }^{1}$ On Francis Glisson, see Temkin 1964; Pagel 1967; Henry 1987; French 1994, 286-309; Giglioni 1996a; Duchesneau 1998, 183-196; Rey 2000; Giglioni 2002a; Giglioni 2002b; Hartbecke 2005; Hartbecke 2006; and Cardoso 2008, 78-84.

${ }^{2}$ See also Haller 1757-1766, IV, 461: "Franciscus Glisson, qui universis elementis corporum vim motricem tribuit, etiam nostram vim Irritabilitatem vocavit, non quod absque irritatione nunquam adpareat, sed quod ab irritatione certa succedat. Eam tamen vim partim a perceptione quadam naturali pendere posuit vir. Cl. et partim a sensu externo, aque stimulo sanguinis in corde docuit cieri. Eam etiam cum omnibus corporis humani partibus communem fecit, ut ipsa ossa succosque demum nostros faceret irritabiles. Manifeste adeo omne contractionis mortuae genus cum nostra vi conjunxit. Caeterum a motu nervoso recte distinxit, qui ab imaginatione nascitur." ${ }^{3}$ Haller 1776-1777a, III, 663a: “Cette... force, qu'il vaudroit mieux appeller force innée, mais qu'on s'est accoutumé à appeller irritabilité.”
} 
the very obscurity - both conceptual and stylistic - of Glisson's work), in the end it was the very eighteenth-century universe of epistemological and philosophical expectations that made Haller's diluted version of Glisson's theory of irritability more palatable to the scientific taste of physiologists and savants.

\section{Metaphysical irritability}

For an anatomist or physician who deals with matters related to the phenomenon of life, metaphysics can hardly be avoided, reluctant as he may be to undertake this kind of investigation. Of the two main figures I shall deal with in this essay, Glisson was certainly the less reluctant "metaphysician." The story goes that after having started his successful program of anatomical investigations focused on the organs of the abdomen (the splendid product of which was his Anatomia hepatis, published in 1654), Glisson interrupted his dissections and experiments on the intestines and the stomach to meditate on the ultimate nature of life. Glisson's philosophical inquiries lasted for around twenty years, leaving a hefty tome on "the energetic nature of substance" (1672), as well as a large number of philosophical manuscripts now kept in the British Library. The most important outcome of this philosophical interlude was his theory of irritability. By contrast, Haller's story is far less metaphysical and scientifically more successful. In a Newtonian vein, he claimed not to have introduced any speculative hypothesis (hypothesin nullam admisi) and he especially liked to hide his philosophical assumptions behind an experimental truism: "I claimed only those parts to feel or to move that I had seen feeling and reacting" (Haller 1757-1766, VIII, v). ${ }^{4}$ If there is any moral here, it is that Haller counted his experimental chickens before they were philosophically hatched.

According to Glisson's ontology, substance (for which he coined the word biousia, i.e., living substance) is the ultimate foundation of reality. However, since there are constitutive limitations on the powers of human intellect, we can have only imperfect glimpses of an entity that is essentially simple. The principal limitation of the human mind is its inability to grasp, in a single act of intellection, both the concrete and the abstract aspects of reality, the Many and the One, matter and motion, and the other basic attributes of being. As is also the case with anatomical investigations, man's intellect proceeds by "dissecting" entities that in reality are undivided and "alive." The most profound division imposed upon reality by the intellect is the distinction between being and energy. Substance, in Glisson's metaphysics, can be described as either selfsubsistence (subsistentia fundamentalis) or activity (natura energetica). Less abstractly, we can see substance either as matter (materia prima) or as life (vita primaeva) (Glisson 1672, $4,11,187)$. We can also look "atomistically" or "anatomically" at things (i.e., in terms of parts rather than structures) and then the ultimate components of reality will become

${ }^{4}$ On Haller's Newtonianism, see Roe 1984. 
minima naturalia and natural perceptions (ibid., 506-534). While minima naturalia are the smallest units into which matter allows itself to be divided, natural perception represents its deepest level of activity. Natural perception is not a sensation (i.e., an act of self-reflexive perception requiring both a hierarchical layering of perceptions and an articulated structure of matter - materia dissimilaris), but the most original manifestation of vital activity in nature, inherent in each part of matter independently of its form or structure (materia similaris). In this case, too, man's mind can conceptually "dissect" the originally undivided unity of the phenomenon - an immediate act of perceptive awareness - and view it from various angles: as a representation, a tendency, or a motion. The fact remains that there is a seamless continuity of perception, appetite, and motion in every living subject, and since everything in nature is alive, everything is a transient modification of this continuum of perception, appetite, and motion (ibid., 66, 192-194, 209, 307, 335; Glisson 1677, 182).

The process of irritability, in Glisson's philosophy and physiology, represents the way in which this continuum of perceptive energy manifests itself in nature. There can be no irritability without perception (irritabilitas supponit perceptionem, says the title of the first section in chap. 7 of De ventriculo): "The motive faculty of the fibres, if it were not irritable, would be always at rest or it would perform always the same action." Irritability "presupposes perception and appetite in order for the fibre to be stimulated time and again, for once perception presents itself, appetite and motion follow suit according to the law of nature" (Glisson 1677, 168). In Glisson's anatomy, a fibre is not only a structure resulting from the combination of spermatic matter and parenchyma. Functionally speaking, it is also an interlacement of various types of perception, characterized by varying degrees of awareness (unsentient perceptions, sensations, and appetites). Glisson distinguishes three kinds of perception governing the process of irritability: natural perception, sense perception, and perception directed by animal appetite. Through natural perception the fibre is able to perceive the material change it undergoes, that is, to "sense" whether such a change is advantageous or harmful and to move accordingly. Sense perception allows the fibre to be aware (advertere) of the perception occurring in the external sense organs. The perception controlled by animal appetite, finally, is the one whereby the brain moves the fibres of the muscles to perform what it desires to do.

When it comes to the strictly philosophical explanation, Glisson argues that the process of natural perception underlying irritability can be accounted for by referring to either a positive (ratio positiva) or a negative (formalis negatio) explanation. The positive ratio is "the perception of the idea of the object that activates the perception"; the negatio is the structural limit that natural perception encounters when it tries to communicate its whole content to the senses. The negation relies on an "economic" reason based on the renowned Aristotelian axiom that natura non deficit in necessariis: "as nature does not fail in accomplishing its necessary operations, so it does not indulge in supplying superfluous acts" (ibid., 173); which means that nature does not need to grant selfawareness to all natural processes, especially when these can be performed without the 
knowledge of the final end. "Perhaps," Glisson conjectures, "natural perception as a whole cannot be communicated to the senses" (ibid., 174). While natural perception is ubiquitous, self-awareness is strictly limited to few occurrences in nature: "that part only is represented to the imagination and animal appetite which is necessary to foster the propagation of the species and the preservation of the foetus" (ibid., 380). Leaving aside his scholastic vocabulary (ratio positiva and formalis negatio), Glisson's claim is that the natural energy pervading the body can be transformed, by the process of irritability, into sensation; but also that there is a source of unsentience and unknowability in nature that cannot be brought to the light of consciousness. It is on this crucial point that Haller distances himself from Glisson. For Haller, as we shall see in the next section, natural energy cannot be converted into sensation; consciousness has nothing to do with irritability; and the idea of an unconscious life of nature is sheer nonsense. If Glisson explains the emergence of self-awareness in nature by presupposing an original level of elementary awareness, Haller denies that perception in all its forms (from awareness to self-awareness) has anything to do with the process of life.

In De ventriculo, the phenomenon of nausea provides Glisson with the opportunity to expand on his thesis that natural perception can be converted into sense perception but only up to a certain level because of an ineliminable residue of bodily unsentient activity.

There is likely to be in nature a formal and specific object of nausea. However, we cannot know that object through the senses but only through natural perception, for if we perceived the object of nausea through the senses, why would not we express that same object with appropriate words, as we do with the other objects of the senses? Sense perception is a public perception and is communicated to the whole animal. It can be understood by making use of the words given to whatever notion of the senses. Natural perception, on the contrary, is private and as such hidden (occulta) to the whole; nor is there any other way for it to become public apart from being communicated to the brain through a nerve and being converted into sense perception (sensus). I admit that the objects that are known only through natural perception remain private and hidden, and for this reason they are called, not incorrectly, hidden qualities (occultae qualitates). (Ibid., 412)

In Glisson's opinion, there cannot be a form of "blind" irritability, that is, a process of reactivity that is the result of an arbitrary motility in response to an external mechanical action. Real reactions are all from within. ${ }^{5}$ If there is a reaction, however primal and obscure such a reaction may be, there must be an object (formale objectum) that causes the alteration and a representation that translates the alteration into a series of perceptive acts (perception, appetite, and motion). There is in nature a primordial representative

\footnotetext{
${ }^{5}$ On the notion of reactivity and the shift from the Aristotelian complementary concepts of "acting" and "being acted upon" to the early-modern concept of action and reaction, see Möller 1975; Canguilhem 1977; Starobinski 2003; and Heller-Roazen 2007.
} 
activity underlying all vital processes, which takes on different forms and produces different results depending on the parts of the body that are involved in the process. However, the deepest levels of representative activity enacted by the act of natural perception, that is, its ultimate object of perception, cannot be fully represented by the senses. This means that every natural operation is directed, i.e., "enlightened" by an act of perception, but also that there is a nucleus of perception that escapes sentient knowledge. Not all knowledge in nature can be resolved into intentional sentience. What is gained in the "public" knowledge of the senses is lost in the "private" knowledge of nature. From a Cartesian point of view - whether strictly or critically Cartesian - such a notion of unsentient knowledge is a mere contradiction because there cannot be knowledge without self-knowledge, i.e., there cannot be knowledge without a form of selfhood - and nature, for Descartes and post-Cartesian thinkers, has no self.

What then does the unsentient perception of a simplex objectum advocated by Glisson look like? What is a perception that, by definition, cannot be perceived by the senses? Glisson explains that in the physiological process of nausea, the stomach,

by perceiving itself through natural perception, necessarily also perceives the alteration that occurs in it, and by perceiving this, at the same time it becomes fully acquainted (pernoscit) with the object that is producing the change, insofar as the change is in the making, for the change in its making is the idea of the object that causes the change (alteratio enim fiens est idea alterantis). (Ibid., 417)

Put in less scholastic jargon, this means that natural perception, being completely absorbed in its own perceptive act, perceives other parts of the world only when they happen to enter its perceptive field. In this way, the external reality that impinges on the reactive and representative life of natural perception becomes an "idea" of the altering reality. The thesis that a physical change corresponds to an idea of that very change (alteratio est idea alterantis) presupposes a form of ontological parallelism involving the "inadequate concepts" of matter and life. The altering representation included in the inadequate concept of natura energetica (i.e., life, i.e., perception) corresponds to the material alteration included in the inadequate concept of subsistentia fundamentalis (i.e., matter). As Henry More did not fail to notice, it is a view that is very close to Spinoza's belief in the ontological parallelism dividing thought from extension (mens idea corporis) (More 1679). In Glisson's case, rather than a form of strict parallelism, it is a case of ontological coincidence: the vital process (the alteratio) coincides with the very representation of it in the act of natural perception (Glisson 1672, 167168). The objection, then, is that such a view cannot avoid charges of animism and anthropomorphism. Indeed, wouldn't the notion of vital natural perception be the very pinnacle of animism? Not only does Glisson say that there is a form of natural perception underlying all vital functions. Now he seems to say that such perception is 
somehow aware of its own perceptive activity. Can natural perception still be deemed to be different from sense perception?

While still advocating a difference between natural and sense perception, Glisson makes clear that such a difference is in fact the result of an evolutionary tendency embedded in matter towards levels of increasing self-awareness. When considered from the point of "being" (subsistentia fundamentalis), substance (biousia) means matter endowed with natural perception. All the rest is constituted by innumerable modifications of matter and perception.

From what has been said, it is clear that the positive ratio of natural perception is not destroyed nor is degraded when it is transformed into sensation. Indeed, in a way it is exalted and raised to a worthier nature. For, as public knowledge surpasses private knowledge, as public benefit raises above one person's advantage, so sense perception (sensus) is to be preferred to natural perception. This is the reason why nature shaped so many sense organs, so that the imagination - the public officer in charge of the animal government - may be fully furnished with the knowledge of the actions to perform, seek, or avoid. (Glisson 1677, 174)

There is a nucleus of constitutively unknowable activity in natural perception, but the tendency in nature is to reach increasingly high levels of awareness. It is true that nature cannot reach the level of absolute self-transparency; however, all forms of cognitive self-transparency are rooted in nature and not in a transcendent power, be that the intellect of the ancient philosophers or the divine mind of the theologians. The hallmark of Glisson's vitalism lies in the thesis that there can be no rationality, intelligibility, $\log o s$, disjoined from nature. This principle has a number of implications: there is an intrinsic meaningfulness in nature; human reason cannot cut its ties with the rationality of nature; man's self-awareness is lacking when separated from nature's awareness. While Glisson acknowledges that even the vital economy of nature does not escape the fundamental rule that communicable knowledge and public benefit are superior to private perception and personal interest, he also insists that there would be no public awareness without a vital bond with the private perception of nature. Glisson's theory of matter and his physiological model represent an attempt to explain the conversion of energy into representation, of natural activity into perception, of motion into knowledge. Being aware of the ground that new ideals of sociability were gaining in Restoration England, Glisson advances his philosophical and physiological solution to explain the transition from "private" natural perception (the foundation of life) to "public" sense perception (which is the foundation of higher forms of social and political organization). From this point of view, being fully aware of Descartes' trenchant objections to the very possibility of unsentient perception and sentient life, and precisely so as to circumvent Descartes' dilemma of res cogitans and res extensa, Glisson raises the stakes and goes even beyond the Aristotelian division into vegetative and sensitive soul (De anima, II, 2, 413ab) and the Galenic division into natural and 
animal faculties (De naturalibus facultatibus, I, i) ${ }^{6}$ For him, there is no need to perpetuate the rift between natural and animal faculties because nature is a power that, even in its simplest motions, testifies to a level of primal awareness. It is this idea of a primal awareness underlying the process of irritability that led Haller to reject Glisson's version of animal responsiveness. But where Glisson suggested the possibility of interaction between nature and knowledge, via the process of irritability, Haller would remain a more faithful Cartesian in ruling out all possibility of such interaction.

\section{Haller's "geography" of irritations versus Glisson's "history" of irritability}

Compared with Glisson's system of pan-irritable physiology, in which all the fibres in natural bodies are irritable because endowed with natural perception, Haller's theory of irritability looks like a compendium of experimental directions and protocols to assess the scope and limits of irritable reactions in animal tissues. ${ }^{7}$ While Glisson resorted to metaphysics to make sense of phenomena that he had previously dealt with experimentally and anatomically, Haller confines his interest to cases of animal experimentation that display various forms and levels of contractions. Since "experiments only can enable us to define what parts of the human body are sensible or irritable," he feels he has no other alternative than performing the "cruel torture" of irritating animal tissues through chemical substances, heat, scalpel, by "touching, cutting, burning, or lacerating the part." The result is that the definition of irritability given by Haller is operational, stripped of all speculative connotations: "I call that part of the human body irritable, which becomes shorter upon being touched; very irritable if it contracts upon a slight touch, and the contrary if by a violent touch it contracts but little." When confronted with the question of the ultimate cause of irritability, Haller cannot but acknowledge that the alleged source "lies concealed beyond the reach of the knife and microscope" (Haller [1755] 1936, 8). Unlike Glisson, for whom irritability is an intrinsic property of matter qua matter, Haller limits the presence of irritability to those parts of the body that can be stimulated by an external agent.

This is apparent, for instance, in his explanation of the heartbeat: the cardiac fibres are stimulated by the inflowing blood and respond with a systolic contraction. The "irritable force" is closely connected with the external "stimulus," in this case the circulating blood (Haller [1786] 1966, I, 60, 68-69; Haller 1757-1766, I, 489-494). In a way, this explicative model is not very different from Glisson's earliest account of cardiac contraction contained in his work on rickets, De rachitide (1650), where the

\footnotetext{
${ }^{6}$ For Glisson's critique of Descartes' view of nature, see Glisson 1672, 341-351.

${ }^{7}$ On Haller's experimental program on irritability, see Duchesneau 1982; Monti 1990; Toellner 1997; Monti 1997; Guerrini 2003, 63-65; and Steinke 2005. On Haller's notions of irritability and sensibility, see Lesky 1959; Rudolph 1964; Toellner 1967; Roe 1981, 32-44; Roe 1984; Rey 2000, 139-157.
} 
two terms of the puzzle - the irritans and the irritabile - are still kept ontologically separated (Glisson [1650] 1682, 90-101; see Temkin 1964; Pagel 1967). In Haller's case, irritability is not the property of a system in which all the parts are mutually and alternately irritable; rather it is the result of a bodily process in which the irritating cause is merely a stimulating factor that arouses a reaction in the irritable part through a mechanical process. Here an ontological divide separates the stimulus from the irritable part, and a clear division of labor occurs between the part that is in charge of providing the stimulus and the part that has the ability to respond to it. Such a divide is the unavoidable consequence of the experimental setting, such that the analysis of the phenomenon can only occur by clearly separating the stimulating cause from the responding effect. Unlike Glisson, Haller does not believe that irritability presupposes a source of reactive spontaneity: "Irritability does not act by itself like the dead force. Irritability is the effect of an external violence" (Haller 1776-1777a, III, 663b). From this point of view, what for Glisson represents the proof of the uninterrupted activity of irritability is for Haller a mere form of mechanical elasticity. ${ }^{8}$

It is well known that the distinction between the irritating agent (the stimulus) and the irritable part is the pragmatic criterion chosen by Haller to explore the physiology of irritability and chart the regions of the body that are liable to be irritated. What is more, as every part of the body responds differently or not at all to the experimenter's irritations, it is of the utmost importance for his model to distinguish accurately among the various forces that act within the body. Haller contrasts his definition of irritability with those of elasticity and sensibility. While elasticity is a merely mechanical quality, sensibility presupposes - at least partially - the activity of the soul. By sensibility in the human body, Haller means the ability of the soul to form a conscious perception (appercevoir) "on the occasion of" the impression that "the surrounding bodies exercise on our nerves." Haller's definition of sensibility is based on the functions of the nervous system. He maintains "that all sensation arises from the impression of an active substance on some nerve of the human body; and that the same is then represented to the mind by means of that nerve's connection with the brain" (Haller [1786] 1966, I, 214, 243; II, 32; see also Haller 1776-1777, IV, 779a). The nerve is said to feel since, "if it is touched by any body, a change arises in the soul, through which it becomes conscious of that contact." By body Haller means every kind of material entity which can affect the nerves, including air, heat, and light (Haller 1757-1766b,

\footnotetext{
${ }^{8}$ Haller 1776-1777a, III, 663a: “Cette force morte agit sans interruption, du moins quant à l'effort; et si son action ne s'offre pas aux sens, c'est que l'action d'une autre fibre. La force morte agit même dans le relâchement, losque la force de l'irritation a diminué. Elle agit sans discontinuer, et n'a pas les accès alternatifs de relâchement et de contraction qu'on remarque dans l'irritabilité."

${ }^{9}$ Haller 1776-1777b, IV, 776a: "Sentir, à l'égard de l'homme, c'est appercevoir dans l'ame un changement à l'occasion de l'impression que le corps qui nous environnent font sur les nerfs." See also Haller 1776-1777a, III, 664b; Haller, 1757-1766, IV, 269: "Sentire hic dicimus, populari omnino significatione ejus vocis usi, quamcunque mentis nostrae mutationem, quae ex corporis humani cum mente connexi contactu oritur."
} 
IV, 269). Haller's explanation of the physiological process of sensation is mechanical: movement is the only thing which affects the nerves and through them the mind. ${ }^{10}$

While elasticity, irritability, and sensibility represent the principal forces acting within the body, the muscle is the anatomical unit where the three forces intersect and where the threefold level of biological organization can be examined in the clearest way (Haller [1786] 1966, I, 231-234). The first force - the "contractile power" - is also called dead force "because it continues to be efficacious after death, and so is different from the powers of life" (ibid., I, 226). ${ }^{11}$ The second force is the vis insita underlying all forms of irritability. It is a property specific to life and to the muscular fibre (ibid., I, 232-234; Haller 1757-1766, IV, 446-456). Finally, the third force, i.e., the "nervous power," depends on the action of the nerves. The "nerve alone has feeling; this alone carries the commands of the soul; and of these commands there is neither intimation nor perception in that part, whose nerve is either tied or cut, or which has no nerve." The force which is the cause of sensibility "is not the same with the vis insita. The former comes to the muscle from without; whereas the other resides constantly in the muscle itself. The nervous power ceases when life is destroyed" (Haller [1786] 1966, I, 234-235; see also Haller 1757-1766, IV, 467-470). Not without a certain level of logical awkwardness, irritability is therefore placed as an intermediate entity between the mechanical operations of matter and the cognitive functions of the soul. In Haller's account, irritability and sensibility inhabit parallel universes: irritability is a motion that does not feel, whereas sensibility is a feeling that does not move - provincias irritabilitatis et sensilitatis diversas esse (Haller 1757-1766, I, 488).

The division of the body according to sensible, irritable, and elastic "regions" is presented by Haller as a result of a far-reaching experimental program. However, it would be incorrect to differentiate Glisson's irritable monism from Haller's theory of irritability by contrasting metaphysics with experimentalism (a contrast that for some historians can still be represented as a polarization between pseudo-science and real science) or on the grounds that Haller relies on experiments more than Glisson did. One has only to read De rachitide, Anatomia hepatis and De ventriculo, not to mention some parts of his philosophical work De substantia naturae energetica and many scattered manuscript papers on anatomical dissection and medical experiments, to realize the extent to which Glisson did perform experiments and actively engaged in very important research programs at the College of Physicians in London during the 1640s and 1650s, programs that were based on carefully conducted observations and dissections (Giglioni 2002a). The difference is rather that Glisson acknowledged the limits of experimental philosophy for the understanding of the nature of life and that he felt the need to integrate his biological investigations with speculative ideas.

\footnotetext{
${ }^{10}$ Haller 1757-1766, V, 530: "Motus ubique solus est, qui et in cerebro mentem, et in objecti externi sensatione nervum sentientem adficit."

${ }^{11}$ Haller 1757-1766, IV, 444: "haec vis cum vita nihil commune habet... Ad hanc ipsam potentiam refero mortuae irritabilitatis genus."
} 
Behind his turn to philosophy was not a tendency to explain obscura per obscuriora, but the realization that the explanation of the causal powers underlying vital processes required preliminary theoretical assumptions to frame experiments and observational data into a meaningfully coherent context. If there was a form of experimental evidence that both Glisson and Haller agreed could not be bypassed, both theoretically and observationally, it was the fact of contraction. The tendency to contract, twitch, wrinkle, and quiver manifested by some animal tissues indicated for both anatomists a primordial manifestation of life. On this point, Haller like Glisson abandoned the Cartesian assumption that there was no life in the bodily parts of the human "statue." In this respect, to talk of anatomia animata for Haller's physiology is legitimate. He acknowledged the specific nature of irritability and considered it to be a sphere of vital activity independent from both perception and inert matter. But while Glisson introduced the notion of irritability to demonstrate that the very fact of irritation in nature presupposed the ability to respond to irritations, Haller was unwilling to accept the full import of the word irritabilitas or to use the word irritabilitas with all its implications. In the final analysis, a fundamental ambiguity lingers in Haller's position, which is an indication of the uneasiness with which he addressed the animate character of his anatomia animata.

Let us focus on this key point by contrasting Glisson's and Haller's positions more closely. Whereas Glisson maintains that there is a transition from irritability to sensibility, from both an anatomical and a cognitive point of view (duplication of bodily parts, in the first case, and duplication of perception in the second) (Glisson 1672, "Ad lectorem," sigg. b2 $2^{\mathrm{v}}-\mathrm{b} 3^{\mathrm{r}}, 183,237$; Glisson 1996, 26), Haller is in favor of a complete separation between the two domains, both anatomically and cognitively. Irritability, Haller argues, "is so different from sensibility, that the most irritable parts are not at all sensible, and vice versa, the most sensible are not irritable" (Haller [1755] 1936, 25; see also Haller 1776-1777a, III, 663a). Glisson explains the transition from irritability to sensibility in proto-evolutionary terms: it is in the very nature of things that natural perception evolves towards sense perception, namely, that matter develops to reach increasingly higher levels of awareness. By contrast, Haller resolutely denies that elasticity is just another form of irritability that is "less aware" than sensibility or that sensibility is a form of irritability that is "more aware" than elasticity.

Glisson is interested in the genesis and development of irritability - its "history," so to speak - reconstructing the stages through which natural perception grows increasingly more irritable, that is, more aware of its own perceptive nature so as to become communicable first to the imagination and then to the mind. Haller, on the other hand, describes a "geography" of irritability, in which "islands" of sensibility are surrounded by seas of "unorganized" animal glue, i.e., the basic material constituent of irritability. For Glisson all parts of the body are irritable (tota constitutio corporis qua irritabilis), although not all of them are sensible. He distinguishes three types of irritability in the fibres (natural irritability, irritability depending on the external senses and irritability that is under the control of the imagination) and, more generally, three 
types of irritability corresponding to the three bodily systems characteristic of the old anatomical tradition (constitutiones corporis), that is, natural, vital, and animal. The natural constitution is the most original and represents the ultimate foundation of the life of the body. It is ruled by natural perception, which extends its action to all the parts of the body, "parenchyma, bones, marrow, fat, blood, nutritive juice, the humours of the eyes and the like, which are all irritable" (Glisson 1677, 194-196). On the contrary, Haller rules out the possibility that there can be anything irritable in the animal body apart from the muscular fibre (Haller [1755] 1936, 40).

Glisson distinguishes between "inorganic" (similaris) and "organized" (dissimilaris) matter, but natural perception - the source of all life and irritability in the body - is intrinsic in matter qua matter independently of its level of organization. Haller, too, differentiates between simple matter and organized matter but for him the emergence of life, irritability, and sensibility is strictly dependent on specific structures and degrees of organization in matter. In both cases, the autonomy of material forces in nature is guaranteed, but Haller, unlike Glisson, maintains the existence of an unbridgeable gap between the sphere of knowledge and that of material mechanism, and knowledge the exclusive property of the soul - has no real anatomical basis.

Glisson's genealogy of irritability leads from the constitutio irritabilis of the body taken as a whole to its smallest components, that is, minima naturalia and natural perceptions. They are the anatomical and physiological building blocks of the irritable body. Haller, too, attempted a genealogy of the basic material conditions of irritability, but the theoretical scope of his exercise in micro-anatomy is narrower than Glisson's panirritable anatomy. To cut a long story short, Haller's argument goes as follows: Only muscular fibres are irritable, and since the muscular fibre is made up of earthly particles and glutinous mucus, and the earthly element has nothing of the flexible and tight nature that make fibres contractile, gluten must be the ultimate source of irritability in nature. Haller admits that experiments are "too gross" in this area, therefore the only foundation of this argument is analogical: the irritability of the animal gluten is a basic property of living matter as attraction and gravity are properties of matter in general (Haller [1755] 1936, 40, 42, 45). While Glisson's "atomism" of minima naturalia and natural perceptions aims at demonstrating the ubiquitous nature of natural responsiveness down to the smallest particles of bodily matter, Haller's analysis of the microstructures of irritabilis natura is an attempt to extend the universal economy of the basic forces of nature to the life of the body (Haller 1757-1766, I, 8-19; IV, 464; Haller [1786] 1966, I, 9-15; Sonntag 1983, 93).

In the end, if we put aside the hackneyed interpretative device of contrasting metaphysics with experimentalism, the chief difference between Glisson's and Haller's views on irritability can be reduced to their differing views on life and knowledge. Haller remained more loyal than Glisson to the pre-modern Platonic, Aristotelian, and Galenic model of a tripartite organization of the life of the body (i.e., life, the senses, and the mind), although this model is updated and standardized by the guidelines of Cartesian dualism and Newtonian dynamics). On the contrary, Glisson annulled 
the structural divisions of classical physiology by adopting a genetic approach meant to show that matter, even in its unorganized state (materia similaris) was capable of self-organization because capable of self-perception. The key point is that a definite philosophy of life underpins both Glisson's and Haller's experimental anatomies. Both authors have been labeled as vitalist. The question then becomes: what does their vitalism look like?

\section{The emergence of the modern notion of consciousness and the end of nature's selfhood}

What is vitalism? I can think of three meanings that have gained currency in the history of science and philosophy: a derogatory sense whereby "vitalistic" is almost synonymous with "mystical" and "irrational"; a loose definition applicable to any doctrine stating that life processes cannot be reduced to merely mechanical dispositions of matter (the "form" of life is more than the sum of any material parts, and design is not the result of random motions of matter); and, finally, a strict definition elaborated in a particular historical moment, according to which vital processes cannot be reduced to physical and chemical phenomena and therefore must be governed by autonomous forces different from the ones acting in non-living matter (a definition of vitalism formulated by Hans Driesch at the beginning of the twentieth century). On a more general level and paying attention to the early-modern intellectual context, vitalism may be seen as the almost inevitable outcome of a cultural situation that was being shaped by fundamental post-Cartesian aporias concerning life and matter: it is only when the reality of life is philosophically questioned in the most dramatic way (life is only a phenomenal appearance created by a specific disposition of matter) that life needs to be philosophically and emphatically reasserted. And it is only by addressing the Cartesian objection in its full force (life is an animistic projection imposed upon inert matter) that vitalism can be taken seriously. It is for this reason that the discussion on irritability and the plausibility of the vitalistic option in the eighteenth century, more than being confined to the sphere of experimental protocols on twitches and spasms, took on the aspect of an investigation concerning the boundaries defining matter, nature, and knowledge. As soon as animism cast its shadow on eighteenthcentury discussions of life, the question of the nature and role of consciousness became of crucial importance.

Taking the above classification as a point of reference, I shall characterize both Glisson and Haller as vitalist in a loose sense. In the portrayal of Glisson's vitalism, a certain intellectual disdain has often prevailed, a disdain which Haller seems to have escaped thanks to his Newtonian credentials. (The historiographic vulgate has it that Haller managed to overcome Glisson's animism by purging his theory of irritability of all references to souls and archei.) From the point of view of the technical, strict definition of vitalism, neither are vitalists, in the sense that they do not believe in the 
emergence of vital qualities that transcend the level of inert matter (Jean Fernel would be the example of a vitalist in this sense, with his theory of a forma totius of celestial origin). For both Glisson and Haller, life is in matter, but for the former it is already in matter in its unorganized state, in the form of natural knowledge, while for the latter life is the result of forces that organize matter without having any knowledge of their organizing tendencies. For Glisson, from the most obscure perception inherent in the vital nature of a stone to the self-transparent intellection of God's mind, life is knowledge; for Haller, although its nature cannot be brought back to a purely mechanical attribute of matter, life is too close to the absolute opaqueness of inert matter to be deemed to have some sort of cognitive autonomy.

Haller is evasive about the nature of knowledge and consciousness. However, there is a page in the Dissertation on the Sensible and Irritable Parts of Animals in which for a moment he seems to step out of his carefully crafted role of the strict experimentalist to venture into the treacherous domains of philosophical interpretation. Here his impeccably descriptive and cataloging approach to the question of irritability yields to a blatantly speculative hypothesis concerning the nature of life and its relationship to consciousness. The passage is worth quoting in full:

The soul is a being which is conscious of itself, represents to itself the body to which it belongs, and by means of that body the whole universe. I am myself, and not another, because that which is called I, is changed by every thing that happens to my body and the parts belonging to it. If there is a muscle, or an intestine, whose suffering makes impressions upon another soul, and not upon mine, the soul of that muscle or intestine is not mine, it does not belong to me. But a finger cut off from my hand, or a bit of flesh from my leg, has no connexion with me, I am not sensible of any of its changes, they can neither communicate to me idea nor sensation; wherefore it is not inhabited by my soul nor by any part of it; if it was, I should certainly be sensible of its changes. I am therefore not at all in that part that is cut off, it is entirely separated both from my soul, which remains as entire as ever, and from those of all other men. The amputation of it has not occasioned the least harm to my will, which remains quite entire, and my soul has lost nothing at all of its force, but it has no more command over that amputated part, which in the meanwhile continues still to be irritable. Irritability therefore is independent of the soul and the will. (Haller [1755] 1936, 28)

The beginning of the passage - "The soul is a being which is conscious of itself, represents to itself the body to which it belongs, and by means of that body the whole universe" - is a philosophical statement with obvious allusions to the philosophical positions that were predominant between late seventeenth and early eighteenth centuries. The emphasis on consciousness is a direct consequence of the Cartesian assumption that the cogito represents the foundational act of human thinking; the insistence on the soul as a representation of the body is reminiscent of Spinoza's definition of the mind as idea corporis; the possibility for the whole universe to be the representative field of the soul, finally, echoes Leibniz's notion of the monad as 
a mirror of the cosmos. In all three cases, the soul was held to be radically different from the body. And yet the idea that the soul by being originally self-representative is also able to represent the rest of the world through the perception of itself being modified by the body dovetails with Glisson's definition of natural perception that we have given at the beginning of this essay. Indeed, even earlier than Glisson, it is a definition contained in one of his acknowledged sources, namely, Tommaso Campanella's De sensu rerum (1620), in which sensibility, understood as a form of sensus sui, stands for original receptivity and impressionability. And if we want to continue in this quellenforschend exercise, we should then remember that Campanella's source of inspiration was, in turn, Bernardino Telesio's notion of material spirits as biological entities capable of representing material changes to themselves, a view that, through the favorable reception of Francis Bacon, enjoyed a level of good repute in early seventeenth-century England. ${ }^{12}$

It is true that, on a formal level, Campanella, Glisson, and Haller present almost the same definition of the soul. However, once the three definitions are read in the light of their respective philosophies, they take on dramatically different meanings. Campanella, Glisson and Haller represent three ways of being "vitalist" that rely on three different views of sentience and consciousness. In the rest of this essay I shall argue that it is precisely their notions of sentience and consciousness that are of essence to understand their views on life and irritability.

Campanella's definition is relevant here because it provided Glisson with a starting point for his account of sentient and reactive faculties. For Campanella, the act of perception presupposes a faculty of inner receptivity. Each thing "knows the other things not through themselves, but insofar as the perceiving thing becomes like them by perceiving them. Therefore, it perceives them insofar as it perceives itself changed and made like them" (Campanella 1620, 106-107). In Campanella's universe, all things are characterized by inherent receptivity because they are aware of their own being. Such inner self-sentience is the source of their identity and self-preservation. By his own admission, Glisson drew on Campanella's De sensu rerum, but he introduced an important specification: the universal perception of nature cannot be aware of its own perceptive activity, because otherwise there would be no difference between natural and animal operations, between nature and the soul. Campanella, Glisson argued, "assigned to inanimate material beings more than I would like to, that is, sensation itself” (Glisson 1672, 186-187; see Giglioni 1996b).

Glisson's boldest metaphysical point in De natura substantiae energetica is the demonstration that the power of self-perception inhabits matter and there is no need to grant being an original power of self-consciousness (as Campanella did). Matter, insofar as it is substance, "is thoroughly operative and acts from within." Accordingly, "it perceives itself, loves itself, and strives to maintain itself." Matter qua fully-fledged

12 On Telesio and Telesian motives in England, see Walker 1972; Rees 1984; Rees 1996; Giglioni 1996 b. 
substance is both being and action, self-subsistence and self-perception. The attribute of being is reflected by the attribute of representation. An idea or ratio objectiva corresponds to a state of being, and vice versa.

Since its perceptive faculty is intimately present to the corresponding objective ratio or idea, matter necessarily perceives everything that that ratio represents, namely, its actual entity inasmuch as it is subsisting in itself, good and worthy of being loved. Necessarily, then, it also desires and loves its own entity. And since such an idea represents the subsistence of matter as being naturally perpetual, matter enjoys and protects this idea with all its interest and energy, and it does not permit that it be annihilated by any kind of violence. (Glisson 1672, 90-91) ${ }^{13}$

Matter thus necessarily perceives everything that is represented by the idea or ratio constituting its being, but, unlike Campanella's self-sentient nature, matter's perception does not reach the level of actual consciousness. It is primordial awareness, but not self-awareness. Matter's awareness is a condition of receptivity and constant alertness to all sorts of stimuli surrounding its patible nature, a state of diffuse perceptivity below the level of centralized and centralizing self-recognition. Looking at substance from the substance's point of view, Glisson argues that the primary act of substance is to have some sense of itself. Being dimly aware of its own nature, substance knows itself, and it is only by knowing itself that it knows everything else. Glisson characterizes this perception as "natural," as an unsentient drive that knows everything different from itself as a result of its being completely immersed in the knowledge of itself. Through natural perception, the perceptive field of substance includes the whole universe as represented to itself by an act of primal awareness. The result of Glisson's argument is that nature is deemed capable of perceiving the uninterrupted act of perception that constitutes its very being, namely, its primary operation. But here is precisely when Glisson's vindication of natural perception verges on self-contradiction. It seems that, for all Glisson's caveats and distinguos, in the life of substance self-perception remains more fundamental than unconscious natural perception. What is more, is it really plausible to advocate the notion of an unconscious self-perception? Campanella had already said that "every thing knows itself through itself" because a thing cannot know the other things through their very being, but only insofar as it perceives itself affected by them. Is then Glisson's objection to Campanella's sensus naturae still tenable? Glisson is well aware that the identification of natural perception with a form of

\footnotetext{
${ }^{13}$ See also Glisson 1677, "Epistola lectori," sig. * $3^{\mathrm{v}}$ : “non extendo hujus perceptionis objectum ultra ipsum subjectum percipiens, alterationes in se factas earumque causas, et aptitudines ab utrisque resultantes. Necesse autem est, ut percipiens naturale, si quicquam omnino percipiat, seipsum percipiat; quod suae facultati percipienti intime praesens sit: secundo, ut alterationes in se factas earumque causas sciat; quod illae in seipso percepto inhaerent, quodque haec cernantur in effectis, vid. in alterationibus a se impressis: denique, ut aptitudines ab utrisque resultantes noscat; quod virtualiter in utrsique junctis, ut in suis causis, contineantur." See also Glisson 1677, 391-392, 417.
} 
original awareness is "an objection of great moment." Rightly so, because the crucial distinction emphasized more than once by Glisson himself between natural perception (i.e., nature's primordial sense of its own self) and sensation (i.e., self-reflexivity as a secondary product of an evolutionary process intrinsic in matter) seems here to vanish.

It is for this reason that, in order to elucidate the difference between natural perception and sensation, Glisson introduces the distinction between two types of perception-of-perception. A "perceived perception" (perceptio percepta), he argues, can be known either "through the same act through which the object is first perceived" (i.e., irritability), or "through an act that is distinct from and compounded with the first" (i.e., sensation) (ibid., 212). While the first kind of perceptio percepta is a form of primal awareness, in which natural perception perceives its own acts in an unmediated manner, the second kind is the way in which sensation judges of its own cognitive states, that is, a level in which simple awareness becomes self-awareness. The former is an "introverted" tendency that delves deeper and deeper into the life of nature, the other is an "extroverted" drive towards the external world and the development of consciousness. Even when it is considered a perception-of-perception, natural perception is not a cognitive superstructure that controls the lower levels of vegetative life from above and from without. On the contrary, it remains an unmediated form of self-representation that regulates the operations of life from below and from within. The self-representative character of natural perception accounts for the substance's ability to represent and interact with everything that is external to and different from itself, in spite of being completely immersed in its own perceptive life.

By being immediately (not mediately, as in sense perception) aware of its own life, substance has the ability to extend the scope of its perceptive power to include the whole universe. Substance "perceives all these objects in a way through its own representative essence (ratio obiectiva), as if this essence were the faculty's primary object, in which all the rest is represented as somehow affecting it (in quo caetera ut id quodammodo afficientia repraesentantur)" (ibid., 213). Natural perception is so radically inwardly-oriented that substance, regardless of whether it is considered as matter (materia prima) or life (vita primaeva), would be completely withdrawn from everything that is not itself, absolutely impermeable and indifferent to external events and incapable of responding to their influences, were it not for the dim perception of its own nature, precisely the perception that makes substance responsive and irritable. The way Glisson describes the nature of substance - by perceiving itself, substance perceives everything that affects it - makes it clear that the life of matter, far from being severely limited in its reactions to external causes, is inherently susceptible of appetite, motion, and irritability. By being idea suiipsius, substance (or matter qua substance) is not an inert substratum but a living entity (biousia) - spontaneous (without being a "self" that is conscious of its own acts), reactive (without being mechanically set in action). By being active and responsive, substance demonstrates that it has a sufficient level of self-representative energy to be able to maintain its unremittingly changing identity. Unlike Campanella's sensus sui, which reacts by becoming like the perceived thing (I feel the heat because I become heat 
myself), natural perception can be characterized as a form of negative response to the impact of everything that is different from it: it reacts by distinguishing itself from what is not part of its representative field. While Campanella's sensus sui engulfs the whole world within itself because being is primarily consciousness, i.e., radical transcendence (for, in the final analysis, to avoid pantheism, sensus sui cannot be anything other than an instantiation of God's consciousness), Glisson's natural perception is its own representative world, i.e., radical immanence. It is worth remembering here what I said of Glisson's notion of irritability at the beginning of this essay: there is a primal source of life and knowledge in nature - the very reservoir of irritability and responsiveness that cannot be completely raised to conscious perception. It is a primal sense of being, which forms the impenetrably private world of natural perception, never to become public knowledge. Original awareness never reaches the level of fully-displayed selfawareness.

Once we have reached this point (natural perception's self-knowledge is not selfreflexivity), we can say that we have touched the most delicate issue in Glisson's philosophical system. Glisson elaborated the notion of natural perception to solve a host of philosophical difficulties resulting from making knowledge - in the form of an original sense of reality (sensus, if we want to use the pregnant Latin word or sentiment intérieur, to use the French equivalent common in the eighteenth century) the principle of life. In order to account for the purposefulness of the vital operations, Glisson assumed that an obscure and undifferentiated power of self-perception lay at the heart of substance's activity (in some obscure and elementary way, substance must know what it is doing, even though it does not know what the rest is doing). However, if natural perception knows itself, and by knowing itself, knows its own operations aiming at a whole variety of ends, can then natural perception still be characterized as something entirely different from sensation? Glisson tried to solve this baffling question - the arch-Cartesian objection - by insisting on natural perception's characteristic of being thoroughly self-absorbed into its own world, namely, its representative field (its ratio objectiva). Significantly, Glisson described natural perception as a kind of very industrious and solitary activity: natural perception "acts so sagaciously and so wisely at home, and does not judge or do anything outside. It dwells inside, takes care only of itself, lives only for itself" (ibid., "Epistola ad lectorem," sig. c2 ${ }^{r}$ ). The self-representative character of natural perception rests on a primordial and immediate act of self-perception - the one and only object of natural perception is "its own being" (entitas propria).

It becomes clear now why Haller appropriated the term "irritability" while rejecting the underlying metaphysics. To accept Glisson's irritability would have entailed endorsing the abhorrent notion of material selfhood, the reduction of man's consciousness to the tip of a dark and impersonal mass of perceiving particles of matter. For Haller, more than Robert Whytt, it is Julien Offray de La Mettrie's ghost that was evoked by Glisson's vitalism. On the other hand, to tilt towards a solution à la Campanella, positing an original self-reflexivity independent of matter, would have meant to capitulate to 
a form of Stahlianism. Haller unswervingly held to the Cartesian principle that only the soul and acts of perception were characterized by self-awareness. For him, the idea that there could be a form of unconscious or material perception behind the process of irritability was simply an argumentative loophole that hid the blatant inconsistency underlying the very notion of unsentient sentience: "the anatomists are obliged to introduce an insensible sensation, and involuntary acts of the will, that is to say, to admit contradictory propositions" (Haller [1755] 1936, 42; italics mine).

From many remarks and observations scattered throughout his work, it is obvious that Haller's physiology of perception has Cartesian roots: "thought is not the express image of the object, by which the sentient nerve is affected. What in common has the idea of redness with a slightly refrangible ray, separated from the seven portions of the whole ray?" (Haller [1786] 1966, 46). ${ }^{14}$ The apparent accord between the motions impressed on the senses and the corresponding thoughts in man's mind is arbitrary and rests on God's original decision:

it is established as a perpetual law by the Creator, that certain changes, made first in the nerve, and then in the common sensory, shall produce certain new corresponding thoughts in the mind, which have an indissoluble connection with each other; so that, although what we perceive in the world be arbitrary, yet that it is real, and not false, appears plainly from the perpetual agreement of similar thoughts arising from similar affections of the sensitive nerves, in all persons at the same time, from one object, or in one person at different times. (Ibid., 46) ${ }^{15}$

Arbitrary, yet real: as in Descartes's metaphysics, the truthfulness of our knowledge is ultimately guaranteed by God. Perceptions of the world are arbitrary because there is no natural correspondence between things and perceptions, not of the kind postulated by Campanella (things perceive other things by perceiving themselves being changed into other things), nor of the kind advanced by Glisson (things perceive other things only because they perceive everything within themselves). However, a reliable feeling of reality can still be founded on the repetition of consistently recurrent patterns of perception (as in Leibniz's notion of "well-ordered dream") ${ }^{16}$ and, ultimately, on God's good will. This does not prevent, though, the widening of an ontological rift

\footnotetext{
${ }^{14}$ See also Haller 1757-1766, V, 531-533: "Distingui vero debet accurate, et ostendi, neque in cerebro repraesentari imagines rerum, neque in anima... In cerebrum nostrum nihil nisi motus pervenit... Relatio ergo est aliqua inter corpora externa, et id quod in cerebro ab eorum impressione fit, non imago aliqua, neque modulus ... Multo minus omnino mens nostra objectorum externorum imagines et vestigia percipit, dum sentit. Cerebrum, dum videmus, motum aliquem percipit, mens nostra ne motum quidem, multo minus distantias, magnitudinem, et alia, quae vere sunt in corporibus, quae videmus."

${ }^{15}$ See also Haller 1757-1766, V, 534: “probabile fit, recte Cl. viros sensisse, arbitrarium omne esse, quod DEUS nobis de mundo permisit percipere, non necessarium. Potuit aliter color ruber in oculo pingi: aliam in cerebro impressionem facere, aliam in animo ideam excitare." Haller also refers to Herman Boerhaave and George Berkeley's Alciphron.

${ }^{16}$ See Leibniz [1875-1899] 1960-1961, IV, 484; VI, 590; Leibniz 1923-, VI, vi, 375.
} 
between perception and reality. On a specifically physiological level, this means that for Haller irritability is a conventional disposition of motions originally instituted by God within living beings, as sensibility is the arbitrary correspondence among sensations and thoughts that He established at the beginning of the creation (Haller [1786] 1966, I, 237; Sonntag 1983, 95, 97).

It is especially when we look at Haller's definition of sensibility and we consider the reasons he adduces to distinguish irritability from sensibility that it becomes apparent to what extent he relies in fact on the soul as a clearly-defined metaphysical entity. Admittedly, he declares that he is only interested in the "experimental attributes" of the soul. It is also true that the procedure is by elimination and is largely based on probable conjectures (ibid., I, 217-218; Haller 1757-1766, IV, 392-396). The fact remains, though, that the soul, its nature, and location are prominent philosophical concerns for Haller. When he philosophizes, it is because he feels the need to reassert the proper view of the soul and its afterlife. To Robert Whytt, who had used the persistence of irritable contractions after the apparent death of an organism to corroborate the claim that irritability is the original property of life and an attribute of the soul, Haller replies that, on the contrary, the fact that irritability continues after death and even in parts that are cut off from the rest of the body is a proof that the soul has nothing to do with irritability (Haller [1755] 1936, 41). ${ }^{17}$ It is certain, Haller insists vigorously, that "the seat of the soul is in the head" (and therefore is centrally located), and it is also certain that the soul cannot be divided (and therefore is one) (ibid., 27, 41). By reinforcing the validity of the time-honored tripartite system of life (nature, life, and soul), Haller attempts a very sophisticated operation of conceptual triangulation between Glisson's vital materialism, Stahl's animism, and Descartes' mechanical physiology. While he manages to avoid the Scylla of La Mettrie's irritable materialism, his Cartesianism is not so strong as to push him towards the Charybdis of Stahl's radical dualism. However, the problem with trilemmas (in this case, the choice between nature, life, and soul), is that they are less compelling than dilemmas (in this case, thought and matter) and, in allowing more shades, they create blurrier pictures.

In Haller's account, irritability is unambiguously distinguished from sensibility and is never described as the preliminary stage in the development of the sense faculties (as is the case with Glisson). The chief reason is that for Haller to assume that motion and knowledge in the body stem from one source of life would involve the divisibility of the soul and, what is worse, a multiplication of souls throughout the affected body. If that were the case, whenever an irritable reaction took place, it would cause the disruption of the unity and simplicity of the soul. Haller is not the first to denounce this shortcoming. As already remarked by Ralph Cudworth, a contemporary of Glisson and a colleague at Cambridge University, the idea that a living being may result from innumerable perceiving units clustering together would inevitably lead to viewing

${ }^{17}$ On the Haller-Whytt debate, see French 1969, 63-76; Roe 1984, 281; Douglas 1995, 22-23; Steinke 2005; and Frixione 2007. 
nature as an unruly "commonwealth of percipients" (Cudworth [1845] 1995, I, 147). Cudworth published his True Intellectual System of the Universe in 1676. In the same period of time, as we have already seen, Henry More was comparing Glisson's theory of biousia to Spinoza's notion of substance: "Biusianists" - so did More address all potential followers of Glisson's metaphysics - cannot explain how a mass of physical monads coexist peacefully and how these monads can communicate among each other the tasks they intend to accomplish within the larger economy of nature (More 1679, 606-608). Both in Cudworth's and More's case, the alarm caused by Glisson's notion of metaphysical irritability depended on its ethical and political implications. The notion of a peripheral and pluralistic organization resulting from innumerable centers of life and perception disseminated throughout the body could be used to justify a condition of moral indifference and political anarchy. An important twist in the story happened with Leibniz's intervention. In the True Intellectual System of the Universe, Cudworth had obliquely referred to Glisson as Strato of Lampsacus, the bold physicalist of antiquity often taken as a paragon of atheistic naturalism. In Theodicy, Leibniz misinterpreted these references as a dig at Spinoza (Leibniz [1875-1899] 1960-1961, VI, 228, 323). Because of Leibniz's authoritative voice and the popularity of his Theodicy, Glisson's vital materialism became assimilated to the more notorious category of Spinozan vital monism.

But there are also intellectual and institutional reasons that explain why, among some early-modern natural philosophers and anatomists, Spinoza and not Glisson came to be seen a herald of vital materialism, suitable or unsuitable (depending on the viewpoint) for anatomical investigations. Herman Boerhaave, Haller's teacher in Leiden, was a very influential figure in the field of anatomical studies. His Institutiones medicae, published in 1708 , became one of the most successful textbooks of physiology, shaping generations of anatomical students. The book underwent several editions and translations. The English version appeared in 1719 with the title A Method of Studying Physick. In 1739 Haller edited the Institutiones as Praelectiones academicae in suas institutiones rei medicae, providing them with a double set of annotations, one illustrating Boheraave's text and the other containing Haller's own comments. La Mettrie translated the Institutiones in French in 1740. Between 1743 and 1748, he republished his translation adding a commentary in six volumes. For all their differences, these various editions contributed to creating a climate favorable to a tendentially mechanical understanding of the vital functions of the body. For our story, the success of Boerhaave's textbook in all its various incarnations represents an important piece in the historical puzzle concerning Glisson's disappearance from the eighteenth-century picture of irritability. In the sections on digestion and sensori-motor reactions, Glisson's De ventriculo is never cited. Boerhaave referred only to Anatomia hepatis and only for questions of anatomical detail concerning the bile-ducts (Boerhaave 1740, I, 94). In other words, Boerhaave removed Glisson from the picture. Lamettrie, who could have sponsored Glisson's model of material irritability, because of his Boerhaavian training, followed a different materialistc pattern, distinctly post-Cartesian and post-Spinozian. 
The question of whether and to what extent Boerhaave was influenced by Spinoza has been long debated by historians of medicine. Boerhaave knew Spinoza's work and it is likely that his theory of the parallelism of the attributes of substance thought and matter - may have exercised some influence on Boerhaave's version of mechanical philosophy. Unlike strict Cartesianism, Spinozism could guarantee a better understanding of the properties of life and the relationship between matter and perception. Boerhaave understood quite well that the application of the mechanical philosophy to anatomical studies could never happen by implementing the principles of Descartes' natural philosophy and that Spinoza's naturalism, made more malleable once cleared of its speculative asperities, was better equipped to provide a much needed philosophical paradigm for the study of life. Pious as he might have been, Boerhaave gave a definition of the mind in the opening pages of his Institutiones that sounded more Spinozian than Cartesian or traditionally Galenic: "Thought is produced either uniquely through the operation of the thinking substance, or through the change of the bodily state" (ibid., I, 13). In Haller's case, the dominant metaphysical model continued to be a form of post-Cartesian ontological parallelism, with the important specification, though, that Boerhaave's original Spinozan parallelism gave way to Leibniz's emphasis on pre-established harmony and apperception. Descartes', Spinoza's, and Leibniz's positions on the mind and life, with their emphasis on phenomenalism and dualism, were thus eclectically appropriated by Haller and used according to the various requirements of his physiological investigations. ${ }^{18}$

Spinoza was not the only author who, because of his greater fame, eclipsed Glisson's contribution to eighteenth-century discussions on irritability. Jan Baptiste van Helmont, of whom Glisson had sung the paean in De ventriculo (Glisson 1677, 272), managed to maintain some renown throughout the eighteenth century and exercised a remarkable influence on Bordeu and the Montepellier school of medicine. Later in his career, Glisson had enthusiastically embraced the Helmontian model based on the idea of federations of vital archei ruling the body. The significance of Glisson's operation lay in his attempt to free Helmontian natural philosophy from Platonic ideas and souls and to assimilate the sentient activity of the archei to natural perception. ${ }^{19}$ However, Glisson's adoption of the Helmontian notion of "archeal” sentience and his transformation into a mere act of natural, material perception were ignored and

\footnotetext{
18 On Spinoza's notion of life, see Zac 1963; Gueroult 1968, II, 143-189; and Bouveresse 1992. On Boherhaave's supposed Spinozism, see Lindeboom 1968, 264; Cunningham 1990; Cook 2000, 233; Knoeff 2002, 21-51; and Israel 2007. On Boerhaave, Haller, and La Mettrie, see Thomson 1991; Wellman 1992; and Koeler 2007. On Haller and Leibniz, see Toellner 1973. On the philosophical debate on the notions of life and mind after the Cartesian turn, see Giglioni 1995a; Giglioni 1995b; and Des Chene 2001.

${ }^{19}$ Besides Glisson 1677, 267-271, 308-309, 323-324, 529-530, 568-569, see the important manuscript paper in the British Library, Sloane 574B ("De inquietudine"), f. $67^{\mathrm{r}}$ : "per Archeum [Helmont] nihil aliud intendit (ut supra evicimus) nisi naturam rectricem corporis, hoc est naturam qua perceptivam appetitivam et motivam" On Glisson's interpretation of Helmont's natural philosophy, see Giglioni 2000a, 43; Giglioni 2000b; and Giglioni 2002a, 208-221.
} 
Bordeu's reading of Helmont's archeus as a vehicle of sensibility, more original than any form of unsentient irritability, prevailed among the followers of Bordeu's medical views. This view of sensibility, for instance, pervades the anatomical and physiological entries of the Encyclopédie. By crowning Helmont as the real founder of the model of decentralized physiology, Bordeu bypassed Glisson's mediation and went straight back to a notion of sensibility as original power of self-perception (Bordeu, Recherches sur les maladies chroniques, in 1818, 800-801). By ignoring the way Glisson had transformed Helmont's theory of sensibility into unsentient material perception, Bordeu had no qualms about dismissing Haller's milder version of material irritability. Unlike Haller, Bordeu did not find the distinction between irritability and sensibility of any particular significance. In his view, sensibility could be considered as the one source for the entirety of life phenomena. The distinction he acknowledged was rather one of degree, between feeling (sentiment) and merely vital sensibility (sensibilité purement vitale) (Recherches sur l'histoire de la medicine, in Bordeu 1818, 668-669; Boury 2004).

Finally, it was Locke's name, and not Glisson's that became associated with the querelle on thinking matter during the eighteenth century. Locke must have had some acquaintance with Glisson since both were at the service of Anthony Ashley Cooper, the third Earl of Shaftesbury. Indeed, Locke consulted Glisson before performing the famous operation on the suppurating hydatid abscess of Shaftesbury's liver in 1668 . But the extent to which they were acquainted with each other's work remains unclear. They knew each other, but we don't know what they thought of each other. In devising his hypothesis that God could superadd to matter a faculty of thinking, Locke may have drawn inspiration from the very loci of Cudworth's True Intellectual System that were in fact a critique of Glisson's hylozoism. Be that as it may, the story of thinking matter in the eighteenth century lost track of Glisson's name. ${ }^{20}$ As already pointed out, by encrypting Glisson's theory of living and perceiving matter with the abstrusely erudite key of Strato's physicalism, the influential pages of his True Intellectual System were read during the eighteenth century with expectations and anxieties different from Cudworth's original ones.

\section{Conclusion: An accidental metaphysician and a reluctant philosopher}

Before concluding, I would like to recapitulate, in a deliberately schematic and matterof-fact style, the chief points addressed in this essay. The reader will forgive, I hope, the clear-cut divisions, nonexistent in history, and will accept them as an aid to historical understanding. In the very spirit of Glisson's method, we will ask our intellect to proceed like an anatomist, dissecting cognitive experience through the use of "inadequate concepts" (Glisson 1996, 74).

\footnotetext{
${ }^{20}$ See Schofield 1970; Pacchi 1973, 100-105 (as far as I know, Arrigo Pacchi is the one who first identified Glisson as the target behind Cudworth's attack on hylozoism); Yolton 1984; and Yolton 1991.
} 
For Glisson, knowledge is an act of primal awareness embedded in matter and capable of evolving to higher levels of self-reflexivity; for Haller, knowledge is a power of selfawareness confined to incorporeal minds with no basis in matter or life. For Glisson, the life of nature has an irrepressible cognitive dimension but its dominant note is to be an unsentient perception; for Haller, the life of nature is both not cognitive and unsentient. Glisson lays the foundations of all forms of natural sentience upon the unsentient perception of nature; Haller states that the foundation of sensibility lies in a material force. The easiest objection one might level at Glisson would then be: What kind of perception is a perception that is unconscious? The objection for Haller would instead be: What kind of life is a life that does not derive from mechanical unintentionality, nor from vital intentionality? In contrast to Descartes, they both endeavor to preserve the autonomy of life (life cannot be reduced to a mechanism). However, while Glisson cannot be considered a dualist because he regards the two chief attributes of being matter and life - as inadequate conceptualizations of one substance (biousia), Haller is a post-Cartesian dualist for whom the universe is the result of the concurrence of two fundamental res characterized by the respective attributes of extension and thought. Do the attributes interact or do they act in parallel universes harmoniously tuned from the very beginning? For Glisson, the interaction lies at the very core of substance in the form of an original ontological indifference of matter and life, unknowable to both the senses and the intellect; for Haller, there is no real interaction between matter, life, and knowledge because the three corresponding forces of elasticity, irritability, and sensibility do not communicate, nor do they influence each other. Both Glisson and Haller hold life to be a basic aspect of the material universe, but, unlike strict vitalists, they did not consider life to constitute an ontological entity of its own. For Glisson, life is simply another way of looking at the reality of things, which can indifferently be seen as either matter or life; for Haller, life is an experimentally inscrutable property of matter. While Glisson constantly runs the risk of falling into the fallacy of animism, Haller's risk is to revamp the old doctrine of occult qualities (rehabilitated as they may be with the help of Newtonian dynamics). Both authors tread a fine line: Glisson relies on the almost contradictory notion of unconscious perception, Haller on a hardly definable notion of life, which is teleological but unsentient, and material but not mechanical. The fundamental problem with Glisson's theory of irritability is that it rests on a contradiction; the fundamental problem with Haller's theory of irritability is that is rests on a trilemmatic predicament. It may sound like a boutade, but Haller's notion of natura irritabilis is more arcane than Glisson's. If Glisson explains irritability through unconscious perception, Haller falls back on the je-ne-sais-quoi of an unfathomable force inherent in matter. As Cudworth already noticed in his True Intellectual System of the Universe, Glisson did not need God to keep his living substance going, not even to give the initial push; on the contrary, Haller cannot explain the teleological behaviour of natura irritabilis without God's original intervention. Of the two, Glisson fits better in the role of the Enlightenment materialist. 
This series of considerations points to a fundamental difference in their way of looking at consciousness and knowledge in nature. Haller's elusive vitalism was not elusive at all when it came to the place and role of God's and man's minds in the natural world. Here he stated unambiguously the superiority of consciousness over nature, of reason over affect, of man over animal, of public over private (Sonntag 1974). To the scarcely appealing model of unremitting perceptive mutability underlying Glisson's notion of irritability, he opposed the steady-state identity of the soul. As we have seen at the beginning of this essay, Glisson, too, had acknowledged the greater worth of the "public" knowledge of the senses over the "private" perception of nature, but for him the superiority of the senses lay in their ability to convert the flawless stream of natural perception into a higher level of awareness. For all the conversions of the senses and the mind, the original drive of life was seen by Glisson as coming from below. In shifting from Glisson's irritability to an experimental management of series of controllable and manipulable irritations, Haller mediated Glisson's anatomy of the lower body (the bodily area governed by the time-honored "vegetative" soul) with that of the rational upper body through the classical Galenic notion of vital faculty, thus securing the mind's primacy and its control over the body. More than the abstruseness of Glisson's theory of substance, it was his notion of perceiving matter that created embarrassment and led philosophers and anatomists to abandon his theory of irritability. Compared with Glisson's physiological model, which highlighted the aspects of periphery, multiplicity, and centrifugal tendencies, Haller's physiology reasserted the notions of center, oneness, and centripetal trajectories. To Glisson's a priori definition of irritability, Haller responded with a thoroughly a posteriori description of irritable phenomena. Rather than offering a philosophical glimpse of the uninterrupted flow of life, he devised an experimental apparatus to put nature into a condition of forced restlessness. As he acknowledged in the entry "Irritabilite" he wrote for the Supplément to the Encyclopédie, unlike the force morte, irritability is always the effect of "une violence extérieure" (Haller 1776-1777a, 663b).

I hope I have demonstrated with this essay that the disappearance of Glisson's theory of irritability from the eighteenth-century is remarkable on two levels. On a historical plane, eighteenth-century anatomists, physicians, and philosophers dropped Glisson's name quite soon and without making a great fuss about it; historiographically speaking, historians of eighteenth-century irritability and related matters have only hinted at him (when they have done so). There is a reason that is at hand to explain both the historical and the historiographical tendency and it can be condensed into the following simple question: Should one really care about Glisson? After all, he was his own worst enemy, contributing to his own demise by writing of such obscure speculative matters in such a tortuous Latin, fraught with erudite references and scholastic jargon. One might legitimately conclude that Glisson was deservedly forgotten. I have tried, however, to bring back to life this forgotten character, to show that Glisson's disappearance was no coincidence, as his contemporaries were aware. At a time when natural investigations 
were becoming increasingly polarized between mind and matter in the attempt to save both man's consciousness and the inert nature of the res extensa, Glisson's investigation of natural perception did not satisfy the new science's basic injunction not to superimpose perceptions and appetites on nature. Knowledge of nature could not be based on knowledge within nature, i.e., on the very knowledge that nature has of itself; or to look at the same question from the point of view of the human mind - man's consciousness could not be seen as participating in forms of natural selfhood. Through his experiments, Haller thought he had conclusively demonstrated that the response given by nature when irritated did not betray any natural perceptivity, any inner life, any sentiment interiéur. In doing so, he provided the rising communities of experimental physiology with a less bewildering theory of irritability.

\section{Acknowledgments}

I would like to thank Anthony Richardson and Charles Wolfe for revising the English of my text and commenting upon the themes of this essay. Adelino Cardoso has provided some illuminating remarks on Glisson's notion of natural perception. I also would like to express my gratitude to the anonymous referees of an earlier version of this essay.

\section{References}

Boerhaave, Herman. 1740. Institutions de medicine. Translated by Julian Offray de la Mettrie. Paris: Huart and Briasson.

Bordeu, Théophile de. 1818. Euvres complètes. Paris: Caille et Ravier.

Boury, Dominique. 2004. La philosophie médicale de Théophile de Bordeu. Paris: Honoré Champion.

Bouveresse, Renée. 1992. L'idée d'animisme universel chez Spinoza et Leibniz. Paris: Vrin.

Campanella, Tommaso. 1620. De sensu rerum et magia. Edited by Tobias Adami. Frankfurt: Egenolph Emmel and Gottfried Tampach.

Canguilhem, Georges. 1977. La formation du concept de reflexe aux XVII et XVIII siècles. Paris: Vrin.

Cardoso, Adelino. 2008. Vida e Percepção de Si: Figuras da Subjectividade do Século XVII. Lisboa: Edições Colibri.

Cook, Harold. 2000. "Boerhaave and the Flight from Reason in Medicine." Bulletin of the History of Medicine 74:221-240.

Cudworth, Ralph. [1845] 1995. The True Intellectual System of the Universe. London: Tegg (reprint: Bristol: Thoemmes).

Cunningham, Andrew. 1990. "Medicine to Calm the Mind: Boerhaave's Medical System and Why It Was Adopted in Edinburgh." In The Medical Enlightenment of the Eighteenth Century, edited by Andrew Cunningham and Roger French, 40-66. Cambridge: Cambridge University Press.

Des Chene, Dennis. 2001. Spirits and Clocks: Machine and Organism in Descartes. Ithaca: Cornell University Press.

Douglas, Aileen. 1995. Uneasy Sensations: Smollett and the Body. Chicago: University of Chicago Press.

Duchesneau, François. 1982. La Physiologie des Lumières: Empirisme, modèles, et théories. The Hague: Martinus Nijhoff.

Duchesneau, François. 1998. Les modèles du vivant de Descartes à Leibniz. Paris: Vrin. 
French, Roger Kenneth. 1969. Robert Whytt, the Soul, and Medicine. London: Wellcome Institute of the History of Medicine.

French, Roger Kenneth. 1994. William Harvey's Natural Philosophy. Cambridge: Cambridge University Press.

Frixione, Eugenio. 2007. "Irritable Glue: The Haller-Whytt Controversy on the Mechanism of Muscle Contraction." In Brain, Mind and Medicine: Essays on Eighteenth-Century Medicine, edited by Harry Whitaker, Christopher Upham,Murray Smith and Stanley Finger, 115-124. New York: Springer.

Giglioni, Guido. 1995a. "Automata Compared: Boyle, Leibniz and the Debate on the Notion of Life and Mind." British Journal for the History of Philosophy 3:249-278.

Giglioni, Guido. 1995b. "Panpsychism versus Hylozoism: An Interpretation of Some SeventeenthCentury Doctrines of Universal Animation." Acta Comeniana 11:25-45.

Giglioni, Guido. 1996a. "Anatomist Atheist? The 'Hylozoistic' Foundations of Francis Glisson's Anatomical Research." In Religio Medici: Medicine and Religion in Seventeenth-Century England, edited by Ole Peter Grell and Andrew Cunningham, 115-135. Aldershot: Scolar Press.

Giglioni, Guido. 1996b. "Campanella e Glisson. Motivi ilozoistici nella medicina inglese della seconda metà del Seicento.” Bruniana \& Campanelliana 2:237-245.

Giglioni, Guido. 2000a. Immaginazione e malattia. Saggio su Jan Baptiste van Helmont. Milan: Angeli.

Giglioni, Guido. 2000b. "The Language of Imagination in Jan Baptiste van Helmont and Francis Glisson." In Medical Latin: From the Late Middle Ages to the Eighteenth Century, edited by Wouter Bracke and Herwig Deumens, 175-196. Brussels: Koninklijke Academie voor Geneeskunde van België.

Giglioni, Guido. 2002a. The Genesis of Francis Glisson's Philosophy of Life. Ph.D. diss., Johns Hopkins University.

Giglioni, Guido. 2002b. "Francis Glisson's Notion of Confoederatio Naturae in the Context of Hylozoistic Corpuscularianism.” Revue d'Histoire des Sciences 55:239-262.

Glisson, Francis. [1650] 1682. De rachitide... Editio postrema. Den Haag: Arnold Leer.

Glisson, Francis. 1672. De natura substantiae energetica. London: Flesher.

Glisson, Francis. 1677. Tractatus de ventriculo et intestinis. Amsterdam: Jacobus Junior.

Glisson, Francis. 1996. De inadaequatis rerum conceptibus. In Latin Manuscripts of Francis Glisson (1). Philosophical Papers, edited by Guido Giglioni. Cambridge: Cambridge Wellcome Unit.

Gueroult, Martial. 1968. Spinoza. Hildesheim: Olms.

Guerrini, Anita. 2003. Experimenting with Humans and Animals: From Galen to Animal Rights. Baltimore: Johns Hopkins University Press.

Haller, Albrecht von. [1755] 1936. A Dissertation on the Sensible and Irritable Parts of Animals, introduction by Owsei Temkin. Baltimore: Johns Hopkins University Press.

Haller, Albrecht von. 1757-1766. Elementa physiologiae corporis humani, 8 vols. Bern and Lausanne: Bousquet, D’Arnay, Grasset.

Haller, Albrecht von. 1776-1777a. "Irritabilité.” In Supplément à l'Encyclopédie, III. Amsterdam: Rey.

Haller, Albrecht von. 1776-1777b. "Sensibilité.” In Supplément à l'Encyclopédie, IV. Amsterdam: Rey.

Haller, Albrecht von. [1786] 1966. First Lines of Physiology. New York: Johnson Reprint.

Hartbecke, Karin. 2005. "Natur und Selbstbewegung. Die Umdeutung des galenistischen Naturbegriffs durch den Anatomen Francis Glisson." In Der Naturbegriff in der Frühen Neuzeit. Semantischen Perspektiven zwischen 1500 und 1700, edited by Thomas Leinkauf and Karin Hartbecke, 283-298. Tübingen: Niemeyer.

Hartbecke, Karin. 2006. Metaphysik und Naturphilosophie im 17. Jahrhundert. Francis Glissons Substanztheorie in ihrem ideengeschichtlichen Kontext. Tübingen: Niemeyer.

Heller-Roazen, Daniel. 2007. The Inner Touch: Archaeology of a Sensation. New York: Zone Books.

Henry, John. 1987. “Medicine and Pneumatology: Henry More, Richard Baxter, and Francis Glisson's Treatise On the Energetic Nature of Substance." Medical History 31:15-40.

Israel, Jonathan. 2007. "Enlightenment, Radical Enlightenment and the 'Medical Revolution' of the Late Seventeenth and Eighteenth Centuries." In Medicine and Religion in Enlightenment Europe, edited by Ole Peter Grell and Andrew Cunningham, 5-28. Aldershot: Ashgate. 
Knoeff, Rina. 2002. Herman Boerhaave (1668-1738): Calvinist Chemist and Physician. Amsterdam: Koninklijke Nederlandse Akademie van Wetenschappen.

Koeler, Peter. 2007. "Neuroscience in the Work of Boerhaave and Haller." In Brain, Mind and Medicine: Essays on Eighteenth-Century Medicine, edited by Harry Whitaker, Christopher Upham Murray Smith and Stanley Finger, 213-232. New York: Springer.

Leibniz, Gottfried Wilhelm. [1875-1899] 1960-1961. Philosophischen Schriften, edited by C. I. Gerhardt. Berlin: Weidmann (reprint: Hildesheim: Olms).

Leibniz, Gottfried Wilhelm. 1923-. Sämtliche Schriften und Briefe. Darmstadt, Leipzig and Berlin.

Lesky, Erna. 1959. "Albrecht von Haller und Anton de Haen im Streit um die Lehre von der Sensibilität." Gesnerus 16:16-46.

Lindeboom, Gerrit Arie. 1968. Herman Boerhaave: The Man and His Work. London: Methuen.

Möller, Hans-Jurgen. 1975. Die Begriffe "Reizbarkeit" and "Reiz": Konstanz und Wandel ihres Bedeutungsgehaltes sowie Problematik ihrer exakten Definition. Stuttgart: Fischer.

Monti, Maria Teresa. 1990. Congettura ed esperienza nella fisiologia di Haller. La riforma dell'anatomia animata e il sistema della generazione. Florence: Olschki.

Monti, Maria Teresa. 1997. "Les dynamismes du corps et les forces du vivant dans la physiologie de Haller." In Vitalisms from Haller to the Cell Theory, edited by Guido Cimino and François Duchesneau, 41-66. Florence: Olschki.

More, Henry. 1679. Ad V. C. epistola altera. In Opera omnia, II, i, 608-609. London: Maycock.

Pacchi, Arrigo. 1973. Cartesio in Inghilterra. Rome and Bari: Laterza.

Pagel, Walter. 1967. "Harvey and Glisson on Irritability, with a Note on Van Helmont." Bulletin of the History of Medicine 41:497-514.

Rees, Graham. 1984. "Francis Bacon and spiritus vitalis." In Spiritus: IV Colloquio Internazionale del Lessico Intellettuale Europeo, edited by Marta Fattori and Massimo Bianchi, 265-281. Rome: Edizioni dell'Ateneo.

Rees, Graham. 1996. "Introduction.” In Francis Bacon, Philosophical Studies c. 1611-c. 1619, edited with introduction, notes, and commentaries by Graham Rees, translated by Graham Rees and Michael Edwards, xxxvi-lxix. Oxford: Clarendon Press.

Rey, Roselyne. 2000. Naissance et développement du vitalisme en France de la deuxième moitié du $18^{e}$ siècle à la fin du Premier Empire. Oxford: Voltaire Foundation.

Roe, Shirley A. 1981. Matter, Life, and Generation: Eighteenth-Century Embryology and the Haller-Wolff Debate. Cambridge: Cambridge University Press.

Roe, Shirley A. 1984. "Anatomia animata. The Newtonian Physiology of Albrecht von Haller." In Transformation and Tradition in the Sciences. Essays in Honor of I. Bernard Cohen, edited by Everett Mendelsohn, 273-300. Cambridge: Cambridge University Press.

Rudolph, Gerhard. 1964. "Hallers Lehre von der Irritabilität und Sensibilität." In Von Boerhaave bis Berger, edited by Karl E. Rothschuh, 14-34. Stuttgart: Fischer.

Schofield, Robert E. 1970. Mechanism and Materialism. British Natural Philosophy in an Age of Reason. Princeton: Princeton University Press.

Sonntag, Otto. 1974. "The Motivations of the Scientist: The Self-Image of Albrecht von Haller." Isis 65:336-351.

Sonntag, Otto. 1983. Correspondence between Haller and Bonnet. Bern, Stuttgart and Vienna: Huber.

Starobinski, Jean. 2003. Action and Reaction: The Life and Adventures of a Couple. New York: Zone Books.

Steinke, Hubert. 2005. Irritating Experiments: Haller's Concept and the European Controversy on Irritability and Sensibility, 1750-90. Amsterdam and New York: Rodopi.

Temkin, Owsei. 1964. "The Classical Roots of Glisson's Doctrine of Irritation.” Bulletin of the History of Medicine 38:297-328.

Thomson, Ann. 1991. "La Mettrie, lecteur et traducteur de Boerhaave." In Dix-huitième Siècle, special issue: Physiologie et médecine, edited by Mirko D. Grmek and Roselyne Rey, 23-29. Paris: Presses Universitaires de France. 
Toellner, Richard. 1967. "Anima et Irritabilitas. Hallers Abwehr von Animismus und Materialismus." Sudhoffs Archiv 51:130-144.

Toellner, Richard. 1973. "Haller und Leibniz. Zwei Universalgelehrte der Aufklärung." In Akten des II. Internationalen Leibniz-Kongresses (Studia Leibnitiana Supplementa), I, 249-260. Wiesbaden: Steiner.

Toellner, Richard. 1997. "Principles and Forces of Life in Haller." In Vitalisms from Haller to the Cell Theory, edited by Guido Cimino and François Duchesneau, 31-39. Florence: Olschki.

Walker, Daniel Pickering. 1972. "Francis Bacon and Spiritus." In Science, Medicine and Society in the Renaissance: Essays to Honor Walter Pagel, edited by Allen G. Debus, II, 121-130. London: Heinemann.

Wellman, Kathleen. 1992. La Mettrie: Medicine, Philosophy, and Enlightenment. Durham and London: Duke University Press.

Yolton, John W. 1984. Thinking Matter: Materialism in Eighteenth-Century Britain. Oxford: Blackwell. Yolton, John W. 1991. Locke and French Materialism. Oxford: Clarendon Press.

Zac, Sylvain. 1963. L'idée de vie dans la philosophie de Spinoza. Paris: Presses Universitaires de France. 
